\title{
New Concept on Centrifugal Filtration
}

\author{
Gyorgy Ratkai ${ }^{1}$ \\ ${ }^{1}$ Affiliation not available
}

August 31, 2020

\begin{abstract}
Abstract An experimental study of the instantaneous filtrate flow rate is in this work applying a special new technics. The preliminary experiments showed that independently from the processed material and the (steady) filling flow rate the filtrate flow rate proved to be constant. The experimental method was filling the empty basket, revolving with the operational speed. The experimental results opened a new field of investigations that is the application of the filling flow rate as an independent variable. The filtrate flow rate vs. filling flow rate diagrams exhibit characteristic shapes similar to each other: They have a special breakpoint. The position of this breakpoint divides two ranges of the operational field: filter surface under-loaded and over-loaded by the rate of filling, respectively. The loading of the filter surface means the specific filling flow rate relative to the filter area of the machine.
\end{abstract}

\section{Hosted file}

AIChE_maintex.docx available at https://authorea.com/users/354909/articles/478376-newconcept-on-centrifugal-filtration

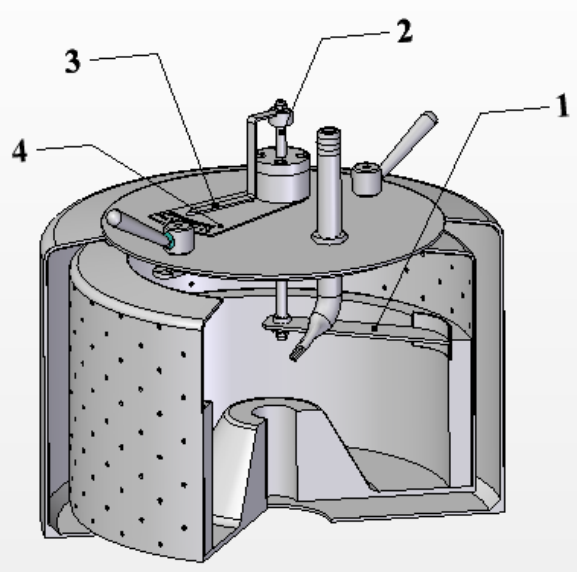



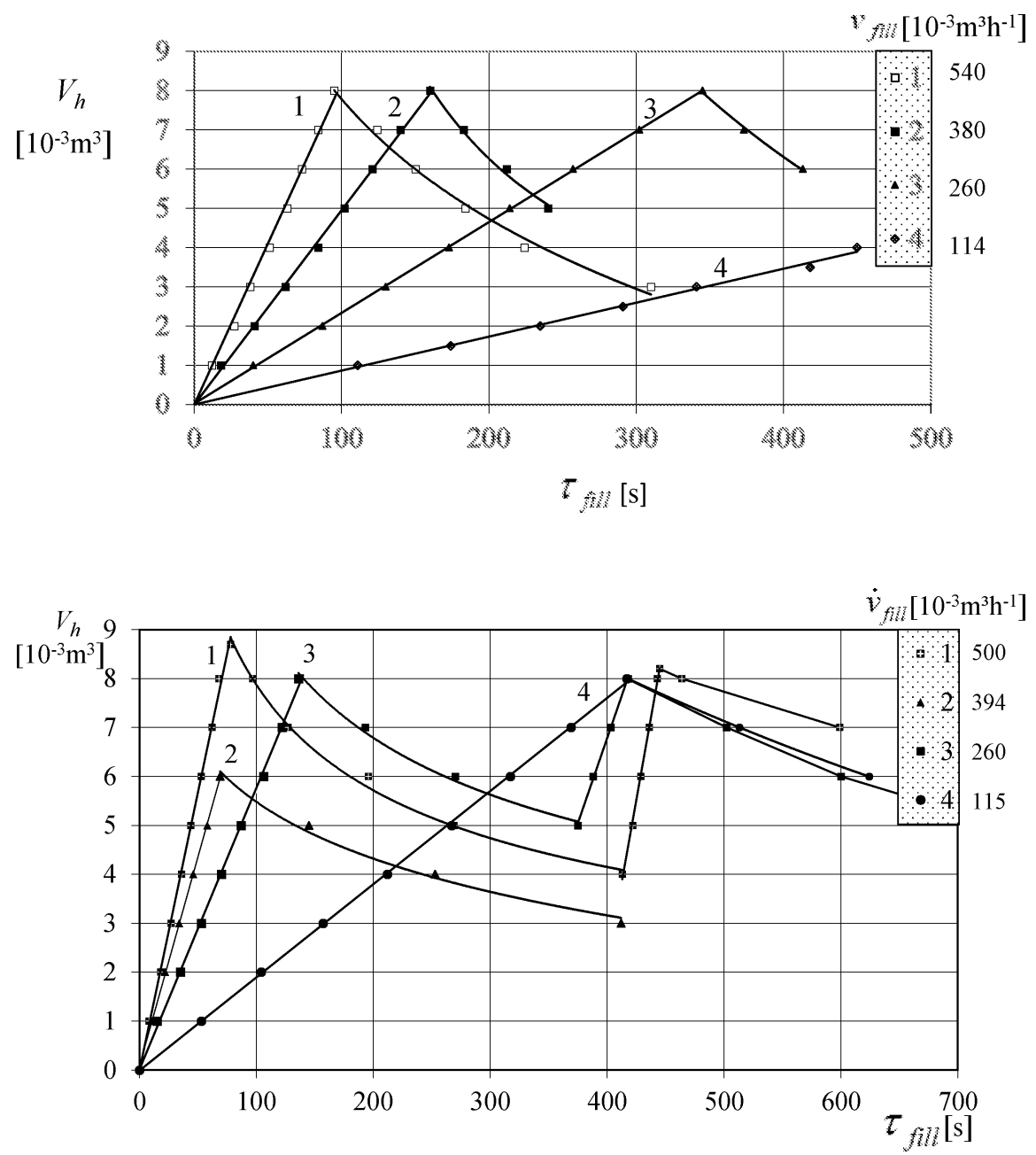



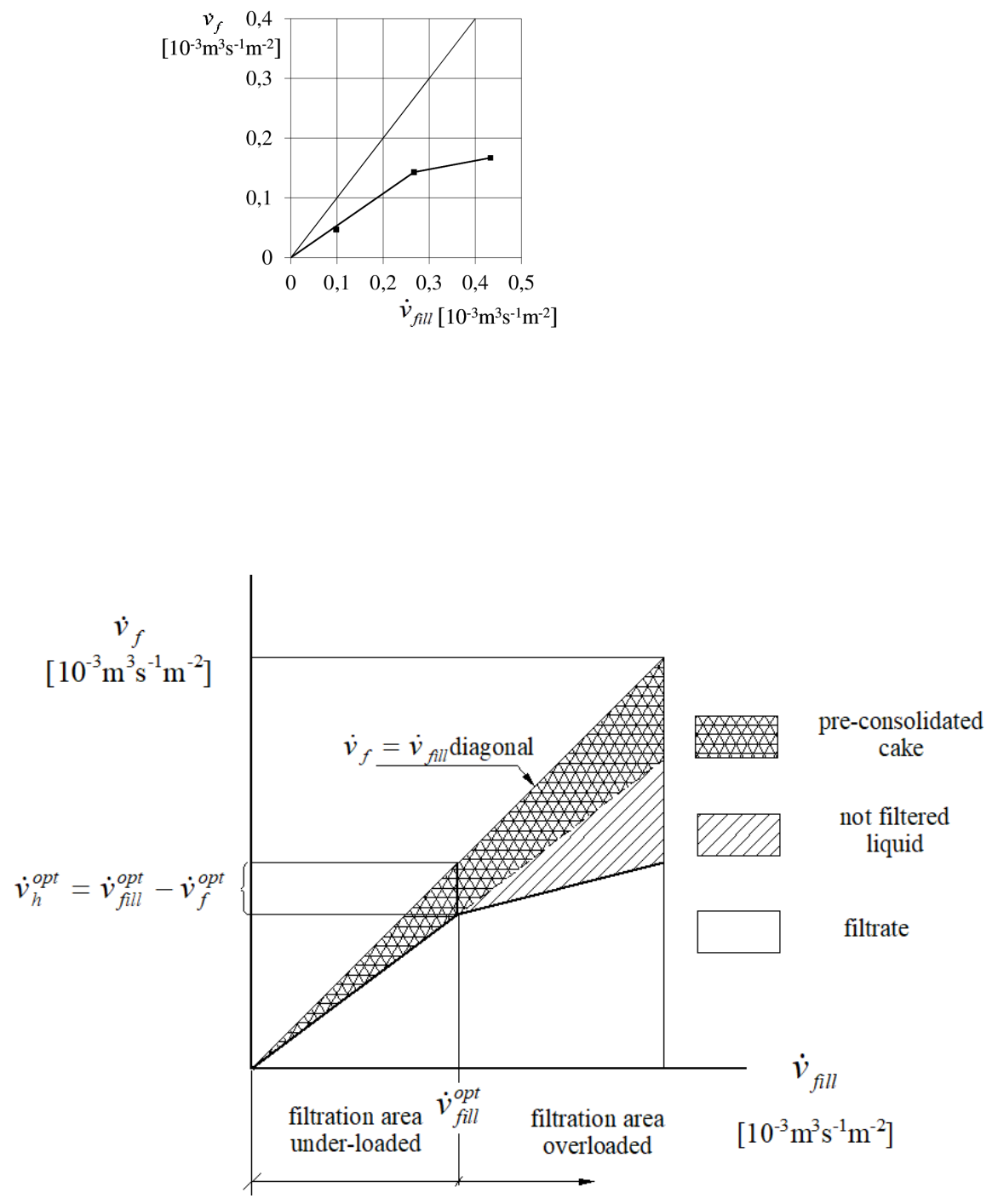

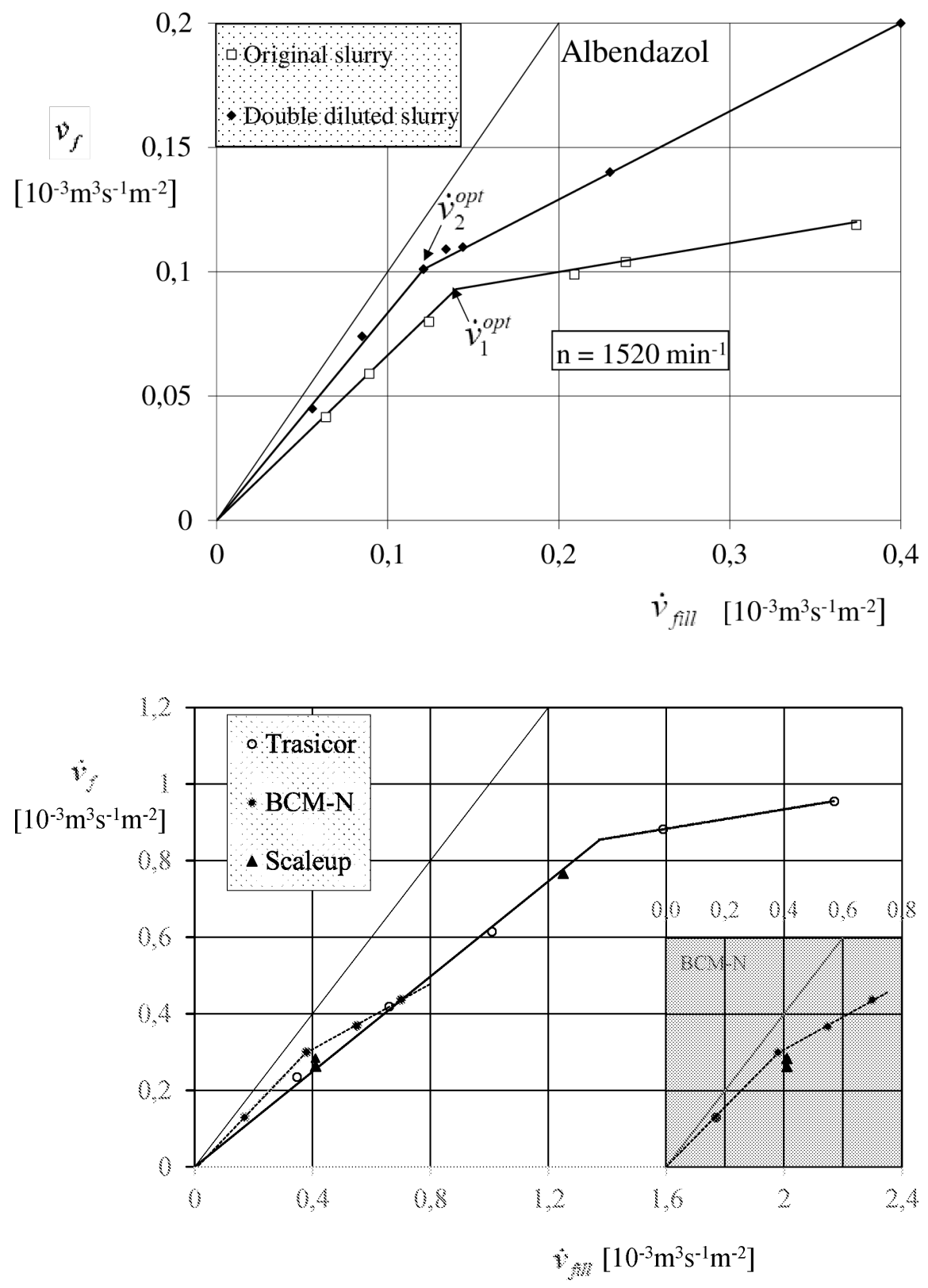







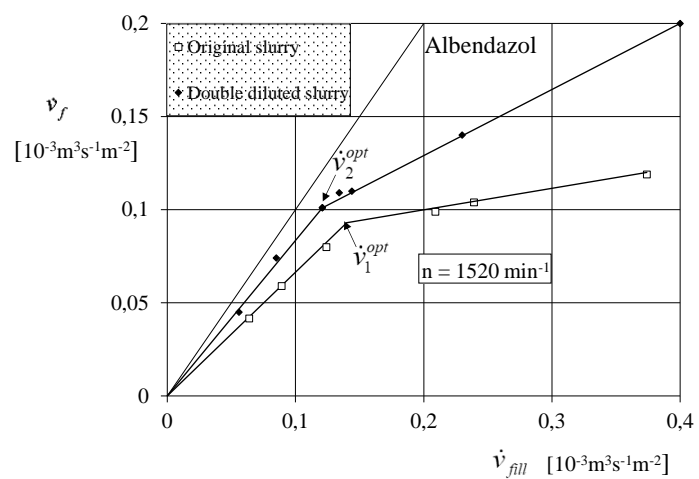

\section{Hosted file}

AIChE_Table 1.doc available at https://authorea.com/users/354909/articles/478376-newconcept-on-centrifugal-filtration

\section{Hosted file}

AIChE_Table 2.docx available at https://authorea.com/users/354909/articles/478376-newconcept-on-centrifugal-filtration

\section{Hosted file}

AIChE _Table 3.docx available at https://authorea.com/users/354909/articles/478376-newconcept-on-centrifugal-filtration

\section{Hosted file}

AIChE_Table 4.docx available at https://authorea.com/users/354909/articles/478376-newconcept-on-centrifugal-filtration

\section{Hosted file}

AIChE_Table 5.docx available at https://authorea.com/users/354909/articles/478376-newconcept-on-centrifugal-filtration 